\title{
Psychopathology of family violence perpetrators: the personality categorization of perpetrators
}

\author{
Danuta Rode $1 \cdot A, B, C, D, E, F, G$, Alison F. Marganski $i^{2 \cdot D, E, F}$ \\ 1: Department of Psychology, University of Silesia, Katowice, Poland \\ 2: Department of Sociology \& Criminal Justice, Virginia Wesleyan College
}

\section{BACKGROUND}

This research explores the psychopathology of family violence perpetrators. In particular, we examine whether it is possible to differentiate between various types of domestic violence offenders based on a profile of personality factors and temperament traits.

\section{PARTICIPANTS AND PROCEDURE}

Males convicted of domestic violence were recruited by psychologists via a center dedicated to supporting courts through psychological diagnoses of family violence offenders. Those who agreed to participate in the study were administered questionnaires and interviewed $(N=325)$.

\section{RESULTS}

After data were collected, cluster analysis was performed on various factors related to psychopathology to deter- mine whether any natural groupings exist. Four distinct subgroups emerged. The subgroups were subsequently analyzed for differences in personality factors and temperament traits.

\section{CONCLUSIONS}

The findings indicate that men who perpetrate domestic violence are not a homogeneous group; they are heterogeneous in nature. Violence perpetrator classifications are described and a discussion follows, along with implications for treatment and recommendations for future research.

\section{KEY WORDS}

family violence; perpetrator; psychopathology; typologies

Corresponding Author - Danuta Rode, Ph.D., Department of Clinical Psychology and Forensic, Department of Psychology, University of Silesia, 53 Grażyńskiego Str., 40-126 Katowice, Poland, tel. +48 8874526 76, e-mail: rode.dan_xl@wp.pl

AUthors' CONTRIBUtion - A: Study design - B: Data collection - C: Statistical analysis - D: Data interpretation . E: Manuscript preparation · F: Literature search · G: Funds collection

TO CITE THIS ARTICLE - Rode, D. \& Marganski, A.J. (2014). Psychopathology of family violence perpetrators: the personality categorization of perpetrators. Current Issues in Personality Psychology, 2(2), 103-117. 
From a psychopathological perspective, harming family members may be associated with a personality disorder or mental illness (Dutton, 2001, 2006) especially for male offenders (Ross, 2011; Ross \& Babcock, 2009), due to a reduced ability to control hostile feelings and aggressive impulses toward another individual. Research has argued that violence against family members reflects an underlying pathology that manifests itself in the context of these relationships (Babcock, Canady, Graham \& Schart, 2007). Recently, research has studied borderline and antisocial personality among male batterers (e.g. Holtzworth-Munroe \& Stuart, 1994; Ross, 2011; Walsh et al., 2010), and it has also investigated whether family violence perpetrators differ from one another or whether they are more alike (e.g. Holtzworth-Munroe \& Stuart, 1994; Walsh et al., 2010). Findings have pointed to diversity among offenders (Hamberger \& Hastings, 1986; Holtzworth-Munroe \& Stuart, 1994), suggesting that different treatment options may be needed. Yet the research to date is limited and has not always taken a broad range of psychopathological symptoms into consideration. This paper will attempt to fill this gap and address our limitations in understanding family violence perpetration. In particular, the current study examines whether it is possible to differentiate between various types of domestic violence perpetrators based on a profile of personality factors and temperament traits. It is hypothesized that this is probable and that different subgroups will emerge, although no specific predictions are made as to how the groups will vary.

\section{LITERATURE REVIEW}

Personality disorders are a bone of contention, with disagreement frequently arising among researchers (as well as practitioners) when it comes to diagnosis and treatment of subjects. Differences in opinions have centered on the essence of the notion of personality disorders, and such conflict has contributed to the lack of conclusive classification criteria, leading to heterogeneity in conceptions that explain the causes and the mechanisms of personality disorders (see Jakubik, 1997; Millon, 1999; Pastwa-Wojciechowska, 2004; Millon \& Davis, 2005; Oleś, 2013). Consequently, many challenges exist in understanding personality disorders. While such disorders have been studied as they relate to family violence perpetration, whether they are correlates or etiological factors in violence perpetration has been subject to debate (Ehrensaft, Cohen \& Johnson, 2006). Nevertheless, further research on personality disorders as they relate to family violence is warranted.

Millon (1996) discusses the issue of personality disorders, differentiating between two levels: functional and structural. Functional personality disor- ders include behavioral symptoms, interpersonal functioning, a cognitive style, and also the mechanisms of the regulation of behavior, whereas structural personality disorders are composed of 'self', temperament, a personality organization type, and also predispositions to perceiving events in one's life and reacting to them. It is important to take both functional and structural factors into consideration when examining offenders for a more complete understanding of their behavior.

In clinical psychology, Jakubik (1997) argues that the essential direction of research into personality disorders involves descriptive theories (i.e. so-called personality trait theories), characterized by classifying individuals from the point of view of their constant psycho-physical properties and predispositions; in other words, examining traits. In accordance with trait theory, personality structure would be a certain system or configuration of traits, and an individual trait would be a succinct description of certain behaviors as well as a determinant of them. Most frequently, personality disorders are divided in two categories: personality structure disorders (pathological personality) and personality trait disorders; assuming that there is differentiation in regards to pathogenesis, clinical personality, course, the degree of permanence, and the exacerbation of disorders, the dynamics and effectiveness of therapeutic methods in use may change. Although some authors have questioned this division (e.g. Hare, 1970), Jakubik (1997) argues that one of the most important benefits resulting from such a division is progress in understanding and treating mental disorders, and the main flaw is the unconditional assumption that they represent particular disease entities rather than generalized knowledge that helps illuminate potentially abnormal conditions.

It is important to emphasize that the functioning of violence perpetrators is characterized not only by the occurrence of personality disorders, but also by other psychopathological symptoms. Domestic violence perpetrators often lack self-confidence and experience various fears resulting from the feeling of lower self-esteem, inefficiency, and being rejected (O’Leary, 1993; Weitzman \& Dreen, 1992). Much research substantiates these claims, suggesting that individuals who harm their female partners have low self-esteem and feelings of powerlessness, in addition to pathological jealousy and anti-social personality disorders, resulting from causes not connected with the relationship itself (see Barnett, Miller-Perrin \& Perrin, 2004; Bennett \& Williams, 1999; Krahé, 2005; Wiehe, 1998).

Furthermore, copious research has found that perpetrators of violence are characterized by low self-acceptance (Goldstein \& Rosenbaum, 1985; Bennett \& Williams, 1999; Wiehe, 1998; Toch, 1993). Self-acceptance is the degree of divergence between 
the "I-real" and "self-ideal" (Reykowski, 1992). A high level of self-acceptance indicates a low degree of divergence between the "I-real" and "I-perfect", while low levels indicate a large discrepancy between the "I-real" and "I-perfect". The latter separation creates emotional tension, which may serve as an incentive for violence (Gasiul, 1993; Jakubik, 1997; Reykowski, 1992). Family violence perpetrators have been characterized by a fragile sense of "I" (Dutton, 2001) and ineptitude (Papadakaki, Tzamalouka, Chatzifotios $\&$ Chliaoutakis, 2009). Therefore, self-acceptance is an important facet to study.

Other research has implied that violence perpetrators have problems controlling their behavior (Baumaister \& Boden, 1988; Jacob, 1987; Johnson, 2006). In an earlier study, Rotter (1975) discussed the locus of control, which is a dimension of personality that helps understand behavior by examining internal and external sources of control. More recently, research on domestic violence offenders has shown that the majority of perpetrators poorly control anger and aggression (Browne \& Herbert, 1999; O'Leary, 1993; Holtzworth-Munroe \& Stuart, 1994; Saunders 1992, 1995). A constant readiness to respond to threats with hostility or violence is common (Berkowitz, 1993; Frączek, 2002). In clinical studies, readiness for aggression has been identified as one of the most important risk factors for violence (Bennett \& Williams, 1999; Wiehe, 1998). Thus, individuals who are quick to anger are more likely to act out. Additionally, when it comes to family violence perpetrators, they often have trouble controlling their anger, become hostile as a response to perceived attacks, and are characterized by negativity and suspicion of others (Buss, 1961). These offenders also often have court judgments indicative of aggression and may hold accounts that conflict with the police (Baumeister \& Boden, 1998; Rode, 2011). They also exhibit low self-control when it comes to risky behaviors including but not limited to excessive alcohol consumption and chain smoking (Krahé, 2005; Kilpatrick, 2004).

A typical feature of perpetrators is an inclination to react impulsively and aggressively to even the slightest provocation (Holtzworth-Munroe, Meehan, Herron, Rehman \& Stuart, 2000). Therefore, perpetrators' violence may be part of a more complex issue that manifests in relationships closest to them. The research of Hamberger and Hastings (1986) supports this, as they discovered that more than $80 \%$ of their clinically examined violence perpetrators were pathological individuals who exhibited various signs of concern. The researchers observed the occurrence of psycho-pathological symptoms such as emotional dependency, depression, fear, low self-esteem, paranoid attitudes, dissociation symptoms, weak impulse control, anti-social tendencies, hostility, and borderline personality traits. As claimed by Kubacka-Jasiec$\mathrm{ka}$ (2006), it is not infrequent that violence perpetra- tors display borderline-type pathologies; ipso facto, their profile reflects the results from clinical examinations.

It has been documented that borderline personality traits are not uncommon among violence perpetrators (Campbell, Sharps \& Glass, 2000; Dutton, 2001; Hamberger \& Hastings, 1986). In terms of importance, borderline personality traits include: an inclination to engage in intense and unstable interpersonal relationships, sometimes characterized by attempts to depreciate a partner; manipulation or concealed dependency; the unstable feeling of 'self', combined with the lack of tolerance towards solitude and a fear of being rejected; strong anger; high expectations; and impulsiveness, usually combined with the use/abuse of stimulants or other potentially harmful substances. Dutton (2001) pointed out that violence perpetrators who exhibit symptoms of borderline personality have substantial difficulties maintaining a stable sense of identity and their self-esteem is very labile, being dependent on the external approval of others. Consequently, this results in a tendency to excessively rely on others. What is more, these individuals suffer from a strong fear of being rejected and losing a partner, so they constantly see a threat where there is no threat, which may contribute to lashing out or externalizing behaviors.

Research has attempted to differentiate several separate pathological personality types on the basis of behavior symptoms in violence perpetrators. According to Kubacka-Jasiecka (2006), they include:

- an unstable and hyperactive personality with weak impulse control,

- a personality that rigidly follows set principles and rituals, having narcissistic or anti-social traits,

- a rebellious personality, having low self-esteem and compulsive properties,

- an aggressive personality, characterized by anger, rage, and anti-social behaviors (psychopathological personality),

- a moody personality (borderline personality),

- a personality sensitive to rejection whereby an individual reacts with aggression,

- a personality having intensified dependency needs, an elevated level of fear and depression,

- a dependent personality and passive-aggressive personality (p. 133).

This reveals that there is great variation in functional personality disorders, as the behavioral groupings encompass multiple typologies.

In addition to these characteristics, research has focused on temperament to differentiate family violence perpetrators. Strelau $(2001,2006)$ examined the core traits that manifest as formal characteristics of behavior (i.e., energy parameters and time), finding that reactivity and activity were the features responsible for the energy level behavior. Dutton and Golant (1995) as well as Herzberger (2002) have made 
it possible to classify perpetrators of domestic violence based on temperament. Some of the research suggests that violence against intimate partners is a means of compensation for a shortage of stimulation. Still, Jacobson (1993) found that about $20 \%$ of those who maltreated partners were characterized by low emotional reactivity in the course of the conflict, indicated by a slow heartbeat and internal calm, even though their behavior was characterized by psychological aggression. Jacobson (1993) proposed that individuals who react in this way efficiently use violence, as their violence is instrumental and controlled. In other work, however, high excitability and excessive impulsivity characterize offenders (Caprara, Perugini \& Barbaranelli, 1994). Therefore, violence perpetrators can differ in aspects of their temperament, which needs to be further researched.

Another component that has received limited attention pertaining to family violence perpetration and personality disorders is that of intelligence. This factor, defined as "the ability to adapt to circumstances by sight of abstract relations, the use of prior experience and effective control over their own cognitive processes" (Nęcka, 2000, p. 726), may help to better understand such behavior. Kaufman and Zigler (1999) identified low intelligence (borderline normal) as a factor contributing to child abuse in the family, among other forms of violence. The authors reported that, due to slow cognitive orientation processes and intellectual limitations, there is a decrease in the ability to problem solve. As a result, when there arise challenges which they are not able to address, they are more likely to act out in frustration due to inadequate education on conflict resolution strategies. Likewise, Caesar (1988) compared a group of men who use violence against their wives with men who do not engage in such behavior and found that some perpetrators exhibit deficits in decision-making functions (the ability to concentrate, abstract reasoning, planning and anticipation of actions, and self-control) that may contribute to their behavior. These perpetrators omitted relevant social cues and misinterpreted the behavior of others. At the same time, family violence is a phenomenon known to occur across all groups and is not limited to those with low intelligence alone. Nevertheless, it is possible that deficits hinder the ability to act in a normative way.

Based on the model concerning the context conducive to family violence (see Rode, 2011), the following research question was formulated: Is it possible to differentiate between various types of family violence perpetrators due to a certain profile of personality factors and temperament traits? After reviewing the literature, a decision was made to differentiate the following personality traits of violence perpetrators: sense of control, self-acceptance, aggressiveness, hostility, IQ, and temperament traits. The research question was one of many that the primary author worked on as part of a model evaluating the contexts conducive to family violence, and, following Gierowski (2000), the model was termed the general motivational background of violence. Personality variables constituted the essential group of factors for the motivational background of violence (for details on workshops and the results of research, see Rode 2010a, 2010b, 2011) and therefore are studied here as well.

\section{PARTICIPANTS AND PROCEDURE}

\section{PARTICIPANTS}

Men who had been convicted of family violence in a Polish court system comprised the sample. Specifically, the study included 325 males over the age of 18 against whom legal proceedings under Article 207, $\S 1$ and 2, had been instituted, or whose case sentences had been passed under Article 207, § 1 and 2, for domestic violence $(N=325)$. In terms of sex and race, the group was homogeneous $(100 \%$ male and $100 \%$ Caucasian, respectively). The average age of the group was around 41 years, and perpetrators of violence were married for an average of 15 years. As for education, almost half of the respondents (49.1\%) had vocational education, over one-quarter $(28.8 \%)$ had secondary or technical school education, and about one out of 20 offenders (4.5\%) had completed higher education. Additionally, nearly three-quarters (74.4\%) of the violence perpetrators were employed while the job situation for the remaining respondents $(25.6 \%)$ consisted of long-term unemployment or maintenance of a minimum pension.

\section{PROCEDURES}

Subjects were recruited from the Family Diagnostic-Consultation Centre, an institution dedicated to supporting courts through psychological diagnoses of family violence offenders. Specifically, six psychologists from across the country who worked for the organization assisted in recruitment and data collection. Males who entered the court system for mistreatment of family members and were convicted of domestic violence were asked to participate in this study. The subjects were informed about the purpose of the study and its procedures. Self-report questionnaires were administered in a total of three or four separate sessions to minimize fatigue and weariness, with each session lasting about one hour. They were also informed that their participation was voluntary, their responses would be anonymous, and they could withdraw from the study at any time. ${ }^{1}$ Interviews were also conducted with the subjects, and court records were subsequently analyzed for comprehensive assessments (see Rode, 2011). 


\section{MEASURES}

The questionnaire included measures from the Polish version of the Wechsler Intelligence Scale Revised (Brzeziński, Gaul, Hornowska \& Jaworska, 2004), Berger Scale of Self-Acceptance (Berger, 1962), Delta Sense of Control Questionnaire (Drwal, 1979), BussDurkee Aggression Scale (1957) (Stanik, Roszkowska \& Kucharewicz, 2006), and Formal Characteristics of Behaviour-Temperament Inventory (FCB-TI) (Strelau \& Zawadzki, 1998).

The Wechsler Intelligence Scale for Adults (WAIS-R) (PL). This scale uses standardized questions and tasks to measure the intelligence expressed in the form of an intelligence quotient. The WAIS-R consists of eleven tests, six that are wordless and five with words. These tests can be used together to estimate a full IQ score.

The Berger Scale of Self-Acceptance. This tool is designed to measure the level of self-acceptance. It consists of 36 items in the form of statements. Respondents are asked to carefully read the statements and then rate the extent to which they describe their own personalities, feelings, behaviors, attitudes and beliefs on a scale of 1 to $5(1=$ Yes, the full truth about me; 2 = Yes, it is true to a large extent; 3 = That's half true; $4=$ This is only true to a small extent; $5=$ No, that's not true). The sum of points obtained indicated the level of self-acceptance. The reliability of the scale measured by Cronbach's $\alpha$ was 0.85 .

The Delta Sense of Control Questionnaire. This measure facilitates a generalized understanding of sense of control, treated as a dimension of personality. It consists of 24 sentences relating to the locus of control (LOC), internal and external, and it also includes 10 sentences on lies (K€). A respondent reads the statements, then marks the answer "yes", "no", or "?". Higher scores on the first part denote an external locus of control while lower scores signal an internal one, and a higher score on the second points to a tendency to present one's self in a favorable light while a lower score implies a less favorable one. The reliabilities of the scales were assessed by two independent methods of calculating the coefficients: absolute stability and internal consistency. For LOC and $\mathrm{KE}$, the absolute stability was 0.79 and 0.80 , respectively. The internal consistency as identified by the Kuder-Richardson method was 0.69 for LOC and 0.54 for KE.

Aggression Scale. This is one of the psychological inventories used to study the severity of aggressiveness and the forms in which it manifests. The inventory includes 75 questions arranged in eight scales (i.e., negativity, resentment, suspiciousness, physical aggression, verbal aggression, indirect aggression, irritability, and feelings of guilt). The participant reads various statements and marks the answer "yes", "no", or "?". Cronbach's $\alpha$ for the scale was as follows: negativity $=0.97$, resentment $=0.96$, suspicion $=0.97$, physical aggression $=0.98$, verbal aggression $=0.98$, indirect aggression $=0.94$, irritability $=$ $=0.97$, and guilt $=0.96$.

Formal Characteristics of Behaviour-Temperament Inventory (FCB-TI). This measure assists in the diagnosis of temperament. The questionnaire includes 120 items, 20 items for each of the six scales (i.e., alacrity, perseveration, sensory, emotional reactivity, resilience, and activeness). Participants respond "yes" or "no" to the items. Cronbach's $\alpha$ for each scale was as follows: alacrity $=0.77$, perseverance $=0.77$, sensory $=0.72$, emotional reactivity $=$ $=0.82$, resilience $=0.86$, activeness $=0.82$. The results in each scale were calculated by summing the number of responses diagnostics (1 point for each answer). Raw scores were standardized according to statins. Interpretation of the results includes two aspects: psychometric and psychological.

Other. Structured interviews were conducted with subjects. They contained questions relating to demographic information, physical health conditions, family of origin information, and marriage as well as one's family of procreation. The Taxonomic Guide to the Acts of the Judiciary (see Rode, 2011 for a brief description) was also used to guide analysis of court records and documents. Information was collected on the histories of the offenders (e.g. previous criminal court record and criminal status), criminal aspects of their violence (e.g. forms of violence, the number of violent acts, whether substance abuse was involved, and the place the violence occurred), and court decisions on punishment. This allowed for comprehensive assessments to be made.

\section{DATA ANALYSIS AND RESULTS}

A total of 325 out of 372 respondents $(87.4 \%)$ participated in the study; 47 subjects excluded were due to attrition or failure to complete all the questionnaires. To detect distinct subgroups from the entire homogeneous group in terms of the selected traits, the data clustering method was used. Data clustering is a procedure based on the similarity of objects, which makes it possible to compare subgroups to each other as well as to the larger group through examination of multiple traits simultaneously (see Borgen \& Barnett, 1987). In the current research sample, clusters were derived from responses to 17 different personal traits (i.e., intelligence quotient, self-acceptance, the sense of control, negativity, resentment, suspiciousness, physical aggression, verbal aggression, indirect aggression, irritability, feelings of guilt, temperament alacrity, temperament perseveration, temperament sensory, temperament emotional, temperament resilience, temperament activeness). The hierarchical clustering method (k-means technique) was used, 


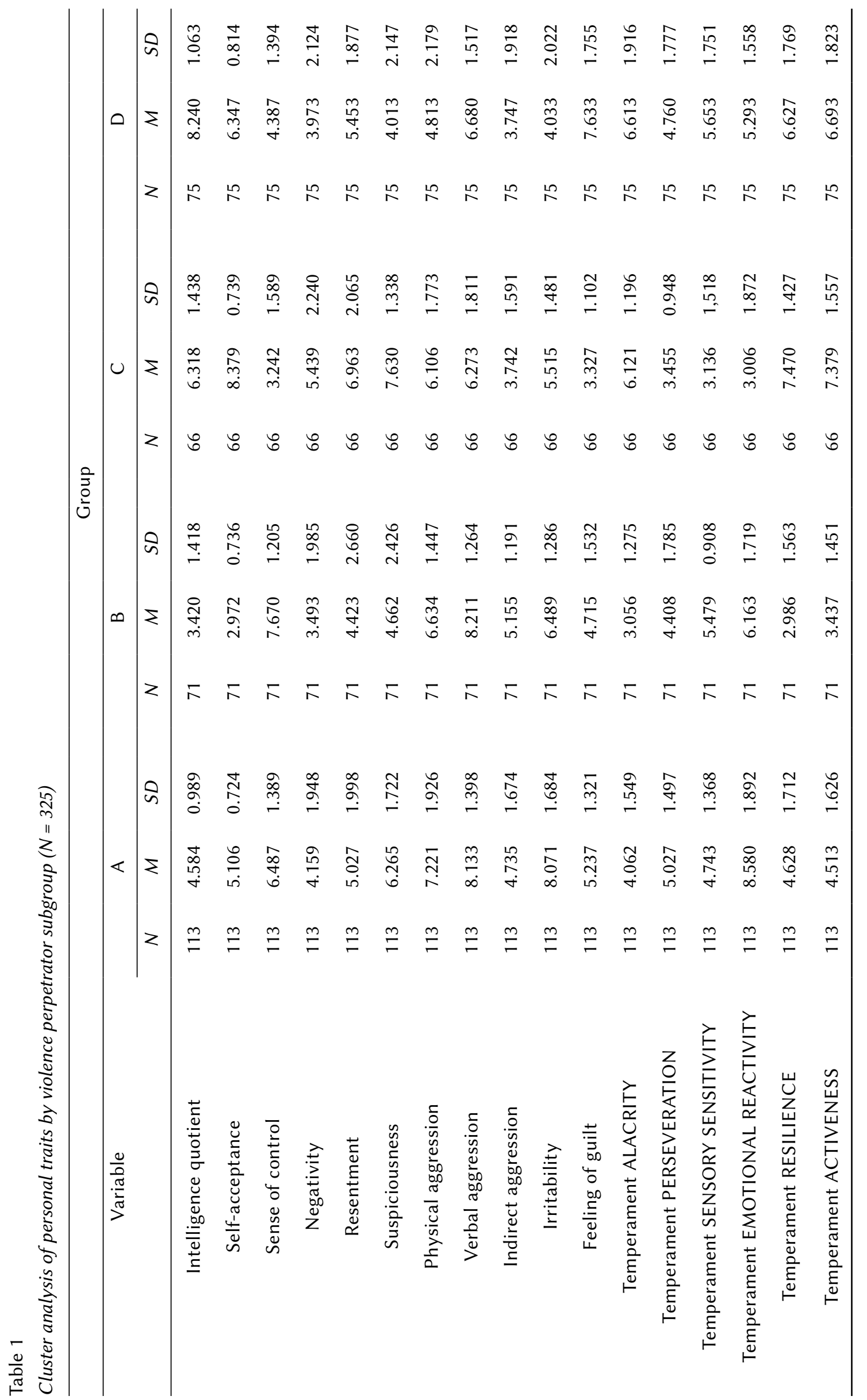


revealing clusters of individuals most similar to each other in terms of their responses.

In the researched group of violence perpetrators, four subgroups (i.e., clusters) emerged, differing in the scope of chosen personality traits. In order to compare the four groups in terms of personality factors and temperament traits, an ANOVA test and the NIR (single-factor analysis of variance, complemented with detailed post hoc tests) test were used. The results of the analyses indicated that there are six personality traits and three temperament traits that differentiate all four groups at the level of $p<0.001$. For personality traits, they are: intelligence quotient, self-acceptance, the sense of control, physical aggression, suspiciousness, and irritability. For temperament traits, they are: emotional reactivity, resilience, and activeness. Table 1 shows the results of the cluster analysis. The final cluster centers (average) for 17 traits are identified in each of the four groups of violence perpetrators.

When using deductive reasoning and focusing on variation within and between clusters, it is possible to state that a certain, forming constellation exists for each of the subgroups, in other words, a system of traits that characterize a given group. Through interpretation, the domestic violence perpetrator groups can be characterized in the following ways:

Group 'A' - Reactively Aggressive Perpetrators $(N=113)$

Men in this group are characterized by substantial emotional excitability, and they react easily and strongly even to the most trivial events. These individuals display an inclination toward impulsive behaviors, are quick-tempered, and readily react in a verbally aggressive way both in terms of form (e.g., shouting, screaming) and content (e.g. bad language and threats) of utterances. They also do not refrain from using physical force against other people and are very irritable; in fact, men in this group scored the highest average among all four groups for physical aggression $(M=7.22, S D=1.93)$ and irritability $(M=8.07, S D=1.68)$, suggesting that they may have a difficult time controlling their behavior. Regulating the behavior of such emotionally reactive perpetrators is achieved at the level of impulsive-emotional structures (the mechanism of regulation is based on emotional behaviors and weakening control mechanisms).

Reactively aggressive perpetrators are characterized by a high level of reactive aggression (aggressive behavior that may be a reaction to stimulation overload, as an effective way of reducing stimulations) and a very low level of demand for stimuli, which results in avoiding situations that have a substantially stimulating value. Because perpetrators somewhat lack cognitive control over aggressive behaviors (intelligence quotient below average), they are unable to actively cope with tasks in difficult situations. Their behavior is determined by stimuli rather than by tasks, and their reactions to situations may include irritation, anger, and wrath, rather than attempting to cope with tasks (moderate self-acceptance, average activeness, alacrity and resilience). They perceive the results of their behavior as remaining beyond their control (a low level of activeness, expressing itself in a small number of behaviors directed towards particular goals). In short, perpetrators in this group have a high level of reactivity, and it is likely that aggression is a reaction to the excessive number of stimuli. Serving to reduce the level of activity, which is higher than the optimal one, may be a valuable form of gratification for them, constituting a strong positive reinforcement; in other words, they learn that violence can be used as a response to situations that overwhelm them (see Rode, 2011 for a detailed description).

Group 'B' - Perpetrators Having a Low Level of Remedial Competencies $(N=71)$

The males in this group are characterized by low intelligence; they had the lowest intelligence quotient scores among the four groups $(M=3.42, S D=1.42)$. They also had the lowest scores for self-acceptance $(M=2.97, S D=0.74)$, negativity $(M=3.49, S D=1.99)$, and resentment $(M=4.42, S D=2.66)$, but the highest scores for sense of control $(M=7.67, S D=1.21)$. It is possible that information is predominantly processed in accordance with the perceptual code rather than the semantic (abstract) one. Men in this group may find it difficult to conduct a cognitive assessment of a situation, to adjust themselves to new and difficult situations, to make decisions, solve problems and accept responsibility for their behavior. Additionally, men in this group have a low level of remedial competencies characterized by a low level of emotional resistibility, weak activity (both work-related and social alike), a low level of behavior flexibility (their ability to analyze and generalize, draw logical conclusions, and use abstract thinking is limited). They display an unstable and a weak sense of control, which is expressed in the lack of feeling safe and their agency (force). They perceive their behavior as remaining beyond their own control, have no confidence in their own abilities, and question the possibility of exerting an influence on the course of events. They are not very resilient or active, and they are poorly prepared for living in society.

In the case of perpetrators having a low level of remedial competencies, impulsive-emotional mechanisms are functionally dominant at the expense of cognitive behavior regulation, which results from a low level of development of cognitive-intellectual structures. In such situations, impulsive and emotional behaviors (a weakening mechanism of emotion control) tend to dominate; they are expressed in a low level of emotional behaviors, which indicates simple forms of diffusing experienced emotions, striving to satisfy their immediate needs, and lacking in overall emotional control. These perpetrators 
are characterized by being unable to reorganize their behavior under the influence exerted by new information and inflexibility (the lack of openness to the inflow of information) resulting from a failure to develop the appropriate strategies of information processing and behavior programming. In the regulation mechanisms of personality of perpetrators having a low level of remedial competences, we observe the underdevelopment of cognitive structures, as a result of which the functional dominance of emotional mechanisms overpowers cognitive structures.

Group ' $C$ ' - Psychopathic-Retributive Perpetrators $(N=66)$

Perpetrators in this group have numerous qualities of a pathological personality: low reactivity and a high demand for stimulation (Hare, 2012; Milton \& Davis, 2005; Hare \& Jutai, 1986), a lack of remorse or feelings of guilt, hostility, emotional shallowness, and efficient intelligence. They are characterized by the pronounced dominance of the impulsive-emotional sphere over the cognitive-emotional one. However, they are capable of relatively emotion-free functioning, even in situations that would cause strong emotional tension in other people, and their internal reactions are cool and controlled. This group of perpetrators scored the highest among all groups in self-acceptance $(M=8.38, S D=0.74)$, negativity $(M=5.44, S D=2.24)$, resentment $(M=6.96, S D=$ $=2.07)$, and suspicion $(M=7.63, S D=1.34)$, and they scored lowest in sense of self-control $(M=3.24, S D=$ $=1.59)$ as well as feelings of guilt $(M=3.33, S D=$ $=1.10$ ). This supports the work of Jacobson (1993) and Dutton (2001), who found that violence perpetrators were cool, focused, and had the ability to suppress reactions of the autonomous nervous system (among others, their heartbeat was slowed down) in spite of the fact that their behavior was characterized by emotional aggression.

Psychopathic-retributive perpetrators try to control external situations by exerting a conscious influence on individuals, most frequently by means of imposing their will and resorting to pressure and threats. They do not care about the needs of other people. They display a low level of emotional sensitivity, and, at the cognitive level, they display an inability to interpret the emotions of other people. The low level of guilt experienced by them makes it possible for such perpetrators to reduce the feeling of responsibility for their behavior and shift the blame onto victims. The aggression of the perpetrators of this kind may be a source of strong stimulation and/ or a mechanism of gaining control and self-confirmation (domination, imposing one's own views as the sole correct ones, and egoism). The self-acceptance indicator may support this suggestion. A very high level of self-acceptance indicates a low degree of divergence between 'the real self' and 'the perfect self', and the regulation standard is 'the real self'; therefore, the behavior regulators are expectations, and behavior is expressed in striving to confirm expectations in order to consolidate 'the real self' (Januszewski, 1992). A small divergence between the two kinds of 'self' (a high level of self-acceptance) is of low stimulating value, which may be one of the causes of constant insufficient stimulation, which is typical in the case of a pathological personality (Eliasz, 1981). Dutton (2001) calls aggressors having such traits psychopathological aggressors, following the opinion of Hare (2012) that an important psychological trait of psychopathology is the lack of emotional reactivity and the lack of feelings of guilt (i.e., lack of a conscience). Dutton (2001) claims that these aggressors resort to calculated violence. The end goal is to control and dominate the other individual, and the perpetrator's behavior is artfully adjusted to the purpose of accomplishing this task.

Group 'D' - Perpetrators Having a Substantial Adaptive Potential $(N=75)$

The configuration of traits in this group indicates that perpetrators have a substantial adaptive potential. Men in this group are characterized by generally high adaptive capabilities and act constructively in frustrating situations, taking feedback from the consequences of their actions into account. This group scored the highest in intelligence quotient average $(M=8.24, S D=1.06)$ and feelings of guilt $(M=7.63$, $S D=1.76)$ among all four groups. They also scored the lowest average for physical aggression $(M=4.81$, $S D=2.18)$, irritability $(M=4.03, S D=2.02)$, and suspicion $(M=4.01, S D=2.15)$, making them amenable to treatment. It is possible to observe a clear cohesion of the structure of 'self' (a relatively high level of self-acceptance, the ability to control oneself, the capacity to control a situation to achieve intended results, being able to predict the course of events, and, importantly, being able to experience the feeling of guilt), which is conducive to the self-confidence of these individuals. It confirms the feeling of identity and self-esteem, and weakens the sense of danger, which reduces a defensive concentration on 'self'. That exerts an influence on the quality of relationships ('self-others') and it makes it possible to treat other people as a source of positive values (Januszewski, 1992; Łukaszewski, 1983; Oleś, 2013).

The functioning of the mechanisms of integration and regulation of the personality of these perpetrators, both at the level of impulsive-emotional structures and cognitive ones, does not cause any controversies. These men have a stable sense of internal control, which is conducive to coping with stress and increases the probability of satisfying various needs such as feeling safe and holding power. They are utterly convinced of the autonomous value of their own person, and a significant mechanism of sustaining and strengthening this feeling is to aim for achievements and accomplish goals. Men in this group are 
perseverant in their action and emotionally resistant. Their aggression, however, may be the result of an uncontrolled reaction to external situational factors, for example, a particular kind of frustration or stress, "provocative" behaviors by partners, or the receipt of information that has hostile connotations.

To complete the cluster-based analysis, external differentiation of the four described perpetrator classifications was performed. The basis for those comparisons was the results of post hoc tests (Tukey's HSD), as seen in Table 2.

Five personality factors and two temperament traits differentiate the subgroups of violence perpetrators at the level of $p<0.001$. For personality factors, they include intelligence quotient, self-acceptance, sense of control, irritability, and suspiciousness. For temperament traits, they include emotional reactivity and resilience.

The findings suggest that intelligence quotient significantly differentiates all the groups in statistical terms. The value of this variable is determined by the average value of stens (i.e., ranking scale). Perpetrators in Group D (i.e., those who have a substantial adaptive potential) possessed a high intelligence quotient whereas perpetrators in Group C (i.e., men who are psychopathic-retributive) had an average level of intelligence. A level of intelligence below normal was characteristic of perpetrators in Group A (i.e., reactive aggressive perpetrators) and Group B (i.e., those having a low level of remedial competences).

Self-acceptance was another variable differentiating all violence perpetrator subgroups at the level of $p<0.001$. The results show a high level of self-acceptance among perpetrators in Group C (i.e., psychopathic-retributive), a very low level of self-acceptance in Group B (i.e., those having a low level of remedial competences), a moderate level self-acceptance in Group D (i.e., those having a substantial adaptive potential), and an average level of self-acceptance in Group A (i.e., reactively aggressive perpetrators).

The sense of control was also statistically significant at the level of $p<0.001$ and differentiates the subgroups of violence perpetrators. Specifically, a very strong internal sense of control is possessed by perpetrators in Group C (i.e., psychopathic-retributive) and a high level of an internal sense of control also characterizes the subjects in Group D (i.e., perpetrators having a substantial adaptive potential) while a very high external sense of control is presented by individuals in Group B (i.e., having a low level of remedial competences) and a high level of external control is typical of the subjects in Group A (i.e., reactively aggressive). Thus, perpetrators in Groups $\mathrm{C}$ and D felt in control of situations whereas perpetrators in Groups $\mathrm{B}$ and $\mathrm{A}$ felt that outside forces shaped their behavior.

Irritability is another personality variable differentiating perpetrators at the level of $p<0.001$. Perpetrators in Group A (i.e., reactively aggressive) have a very high level of readiness to display negative feelings, even with the slightest irritation. Given that this group had the highest level of physical aggression, it comes as no surprise. In comparison, the value of average stens for this variable in Group D (i.e., perpetrators having a substantial adaptive potential) indicated low proclivity for irritation. Group B (i.e., perpetrators having a low level of remedial competences) displayed a relatively high level of an inclination to impetuousness and being quick-tempered, and perpetrators in Group C (i.e., psychopathic-retributive) displayed a moderate tendency to become irritated.

Another statistically significant variable differentiating the groups of violence perpetrators is suspiciousness, expressing itself in projecting hostility in a situation. The results of the average stens of this scale show that perpetrators in Group C (i.e., psychopathic-retributive) are characterized by a high level of suspiciousness and are convinced that their environment is hostile, unjust, or that it plans to harm them. Conversely, perpetrators in Group D (i.e., having a substantial adaptive potential) displayed a trusting attitude towards their environment and a firm belief that other people do not harm others consciously. A moderate level of suspiciousness characterized Group A (i.e., reactively aggressive perpetrators) whereas a low level of suspiciousness and hostility towards others was characteristic of Group B (i.e., those having a low level of remedial competences).

The results of post-hoc tests indicated that two temperament traits, namely emotional reactivity and resilience, significantly differentiate all the violence perpetrator subgroups at the level of $p<0.001$. The average values of stens for emotional reactivity indicated that perpetrators in Group A (emotionally reactive) have a very high level of emotional reactivity while perpetrators in Group C (psychopathic-retributive) have a low level of tendency to react to stimuli. Group B (having a low level of remedial competences) displayed a relatively high level of emotional excitability, even to the most trifling events, and perpetrators in Group D (having a substantial adaptive potential) are moderately emotionally reactive. As for resilience, perpetrators in Group C (i.e., psychopathic-retributive) exhibited a high level of resilience to everyday life, and perpetrators in Group D (i.e., those having a substantial adaptive potential) were characterized by a moderate degree of resilience. The average values of stens for this variable among perpetrators in Group B (i.e., those having a low level of remedial competences) indicated that they had a very low level of resilience. Group A (i.e., reactively aggressive perpetrators) also had a low level of resilience, albeit to a lesser extent, and were incapable of continuing their actions over an extended period of time.

The personality factors of negativity, resentment, physical aggression, verbal aggression, indirect ag- 
Table 2

Results of post hoc tests (Tukey' HSD) of criteria variables in cluster groups

\begin{tabular}{|c|c|c|c|c|c|c|c|c|}
\hline \multirow[t]{2}{*}{ Variable } & \multirow[t]{2}{*}{ Cluster } & \multirow[t]{2}{*}{$N$} & \multirow[t]{2}{*}{$M$} & \multirow[t]{2}{*}{$S D$} & \multicolumn{4}{|c|}{$p$ for Tukey's HSD test } \\
\hline & & & & & A & B & $\mathrm{C}$ & $\mathrm{D}$ \\
\hline \multirow{4}{*}{$\begin{array}{c}\text { Intelligence } \\
\text { quotient }\end{array}$} & $A$ & 113 & 4.584 & 0.989 & - & & & \\
\hline & B & 71 & 3.620 & 1.418 & $<0.001$ & - & & \\
\hline & $\mathrm{C}$ & 66 & 6.318 & 1.438 & $<0.001$ & $<0.001$ & - & \\
\hline & $\mathrm{D}$ & 75 & 8.240 & 1.063 & $<0.001$ & $<0.001$ & $<0.001$ & - \\
\hline \multirow{4}{*}{$\begin{array}{c}\text { Self- } \\
\text { acceptance }\end{array}$} & A & 113 & 5.106 & 0.724 & - & & & \\
\hline & B & 71 & 2.972 & 0.736 & $<0.001$ & - & & \\
\hline & $\mathrm{C}$ & 66 & 8.379 & 0.739 & $<0.001$ & $<0.001$ & - & \\
\hline & $\mathrm{D}$ & 75 & 6.347 & 0.814 & $<0.001$ & $<0.001$ & $<0.001$ & - \\
\hline \multirow{4}{*}{$\begin{array}{c}\text { Sense } \\
\text { of control }\end{array}$} & $A$ & 113 & 6.487 & 1.389 & - & & & \\
\hline & B & 71 & 7.670 & 1.205 & $<0.001$ & - & & \\
\hline & $\mathrm{C}$ & 66 & 3.242 & 1.589 & $<0.001$ & $<0.001$ & - & \\
\hline & $\mathrm{D}$ & 75 & 4.387 & 1.394 & $<0.001$ & $<0.001$ & $<0.001$ & - \\
\hline \multirow{4}{*}{ Negativity } & A & 113 & 4.159 & 1.948 & - & & & \\
\hline & B & 71 & 3.493 & 1.985 & 0.144 & - & & \\
\hline & $\mathrm{C}$ & 66 & 5.439 & 2.240 & $<0.001$ & $<0.001$ & - & \\
\hline & $\mathrm{D}$ & 75 & 3.973 & 2.124 & 0.930 & 0.495 & $<0.001$ & - \\
\hline \multirow{4}{*}{ Resentment } & A & 113 & 5.027 & 1.998 & - & & & \\
\hline & B & 71 & 4.423 & 2.660 & 0.249 & - & & \\
\hline & $\mathrm{C}$ & 66 & 6.833 & 2.065 & $<0.001$ & $<0.001$ & - & \\
\hline & $\mathrm{D}$ & 75 & 5.453 & 1.877 & 0.542 & 0.021 & $<0.001$ & - \\
\hline \multirow{4}{*}{$\begin{array}{l}\text { Suspicious- } \\
\text { ness }\end{array}$} & A & 113 & 6.165 & 1.722 & - & & & \\
\hline & B & 71 & 4.662 & 2.426 & $<0.001$ & - & & \\
\hline & $\mathrm{C}$ & 66 & 7.630 & 1.338 & $<0.001$ & $<0.001$ & - & \\
\hline & $\mathrm{D}$ & 75 & 4.013 & 2.147 & $<0.001$ & $<0.001$ & $<0.001$ & - \\
\hline \multirow{4}{*}{$\begin{array}{l}\text { Physical } \\
\text { aggression }\end{array}$} & A & 113 & 7.221 & 1.926 & - & & & \\
\hline & B & 71 & 6.634 & 1.447 & 0.162 & - & & \\
\hline & $\mathrm{C}$ & 66 & 6.106 & 1773 & 0.001 & 0.350 & - & \\
\hline & $\mathrm{D}$ & 75 & 4.813 & 2.179 & $<0.001$ & $<0.001$ & $<0.001$ & - \\
\hline \multirow{4}{*}{$\begin{array}{c}\text { Verbal } \\
\text { aggression }\end{array}$} & A & 113 & 8.133 & 1.398 & - & & & \\
\hline & B & 71 & 8.211 & 1.264 & 0.986 & - & & \\
\hline & $\mathrm{C}$ & 66 & 6.273 & 1.811 & $<0.001$ & $<0.001$ & - & \\
\hline & $\mathrm{D}$ & 75 & 6.680 & 1.517 & $<0.001$ & $<0.001$ & 0.370 & - \\
\hline \multirow{4}{*}{$\begin{array}{l}\text { Indirect } \\
\text { aggression }\end{array}$} & A & 113 & 4.735 & 1.674 & - & & & \\
\hline & B & 71 & 5.155 & 1.191 & 0.322 & - & & \\
\hline & $\mathrm{C}$ & 66 & 3.742 & 1.591 & 0.001 & $<0.001$ & - & \\
\hline & $\mathrm{D}$ & 75 & 3.747 & 1.918 & $<0.001$ & $<0.001$ & 1.000 & - \\
\hline \multirow{4}{*}{ Irritability } & A & 113 & 8.071 & 1.684 & - & & & \\
\hline & B & 71 & 6.589 & 1.286 & $<0.001$ & - & & \\
\hline & $\mathrm{C}$ & 66 & 5.515 & 1.481 & $<0.001$ & $<0.001$ & - & \\
\hline & D & 75 & 4.033 & 2.022 & $<0.001$ & $<0.001$ & $<0.001$ & - \\
\hline
\end{tabular}

(Table 2 continues) 
Table 2

(Table 2 continued)

\begin{tabular}{|c|c|c|c|c|c|c|c|c|}
\hline \multirow[t]{2}{*}{ Variable } & \multirow[t]{2}{*}{ Cluster } & \multirow[t]{2}{*}{$N$} & \multirow[t]{2}{*}{$M$} & \multirow[t]{2}{*}{$S D$} & \multicolumn{4}{|c|}{$p$ for Tukey's HSD test } \\
\hline & & & & & $\mathrm{A}$ & $\mathrm{B}$ & $\mathrm{C}$ & D \\
\hline \multirow{4}{*}{$\begin{array}{l}\text { Feelings } \\
\text { of guilt }\end{array}$} & $A$ & 113 & 5.237 & 1321 & - & & & \\
\hline & B & 71 & 4.715 & 1532 & 0.201 & - & & \\
\hline & $\mathrm{C}$ & 66 & 3.327 & 1102 & 0.001 & $<0.001$ & - & \\
\hline & $\mathrm{D}$ & 75 & 7.633 & 1755 & $<0.001$ & $<0.001$ & $<0.001$ & - \\
\hline \multirow{4}{*}{ Alacrity } & A & 113 & 4.062 & 1.549 & - & & & \\
\hline & B & 71 & 3.056 & 1.275 & $<0.001$ & - & & \\
\hline & $\mathrm{C}$ & 66 & 6.121 & 1.196 & $<0.001$ & $<0.001$ & - & \\
\hline & $\mathrm{D}$ & 75 & 6.613 & 1.916 & $<0.001$ & $<0.001$ & 0.225 & - \\
\hline \multirow{4}{*}{ Perseveration } & A & 113 & 5.027 & 1.497 & - & & & \\
\hline & $\mathrm{B}$ & 71 & 4.408 & 1.785 & 0.023 & - & & \\
\hline & $\mathrm{C}$ & 66 & 3.455 & 0.948 & $<0.001$ & 0.002 & - & \\
\hline & $\mathrm{D}$ & 75 & 4.760 & 1.777 & 0.654 & 0.516 & $<0.001$ & - \\
\hline \multirow{4}{*}{$\begin{array}{c}\text { Sensory } \\
\text { sensitivity }\end{array}$} & A & 113 & 4.743 & 1.368 & - & & & \\
\hline & $\mathrm{B}$ & 71 & 5.479 & 0.908 & 0.004 & - & & \\
\hline & $\mathrm{C}$ & 66 & 3.136 & 1.518 & $<0.001$ & $<0.001$ & - & \\
\hline & $\mathrm{D}$ & 75 & 5.653 & 1.751 & $<0.001$ & 0.879 & $<0.001$ & - \\
\hline \multirow{4}{*}{$\begin{array}{l}\text { Emotional } \\
\text { reactivity }\end{array}$} & A & 113 & 8.580 & 1.892 & - & & & \\
\hline & $\mathrm{B}$ & 71 & 6.563 & 1.719 & $<0.001$ & - & & \\
\hline & $\mathrm{C}$ & 66 & 3.406 & 1.872 & $<0.001$ & $<0.001$ & - & \\
\hline & $\mathrm{D}$ & 75 & 5.293 & 1.558 & $<0.001$ & $<0.001$ & $<0.001$ & - \\
\hline \multirow{4}{*}{ Resilience } & A & 113 & 4.428 & 1.712 & - & & & \\
\hline & B & 71 & 2.386 & 1.563 & $<0.001$ & - & & \\
\hline & $\mathrm{C}$ & 66 & 7.470 & 1.427 & $<0.001$ & $<0.001$ & - & \\
\hline & $\mathrm{D}$ & 75 & 6.627 & 1.769 & $<0.001$ & $<0.001$ & 0.001 & - \\
\hline \multirow{4}{*}{ Activeness } & A & 113 & 4.513 & 1.626 & - & & & \\
\hline & $\mathrm{B}$ & 71 & 3.437 & 1.451 & $<0.001$ & - & & \\
\hline & $\mathrm{C}$ & 66 & 7.379 & 1.557 & $<0.001$ & $<0.001$ & - & \\
\hline & $\mathrm{D}$ & 75 & 6.693 & 1.823 & $<0.001$ & $<0.001$ & 0.062 & - \\
\hline
\end{tabular}

gression, and the feeling of guilt, and the temperamental traits of alacrity, perseveration, and sensory sensitivity were seen as less important.

\section{DISCUSSION}

The analysis of violence perpetrator profiles leads to the conclusion that personality and temperament are closely related to disordered identity and to the functions of 'self'. A characteristic trait of these individuals is diffusing identity and having an unstable, inadequate picture of one's self, which is commonly characterized by overestimating one's abilities or devaluating them, and sometimes oscillating between those extremities. The structure of 'self' constitutes the main center of regulation and integration of behavior. It integrates the scope of information regarding the external state, outside appearance, physical properties, abilities and skills, needs, attitudes and position among fellow human beings (Reykowski, 1978). Organizing information around the picture and the notion of one's own 'self' is performed by means of separating the internal reality ('self') and the external one ('not self'), and also the mutual relationship of them ('self'-'the world').

In some violence perpetrators, an unclear differentiation of this border occurs; they are controlled by temporary stimuli and external factors, display a tendency to ascribe their own feelings and thoughts to their situation (i.e., projecting), and are sometimes inclined to adopt the views and opinions of others. 
In the course of development, the particular needs of the 'self' are formed, which include the need to preserve the identity and integrity of the 'self' as well as the need to maintain self-esteem and control (Reykowski, 1986). The needs of 'self' are expressed in the demand for information that sustains the notion of one's own 'self', the view of the world, and the relationship between one's self and the world (Jakubik, 1997). The personality disorders of some violence perpetrators is are with a constant failure to satisfy the needs of the 'self'. Additionally, a lack of information or the inflow of information incompatible with the information coded in their structure of the 'self' results in an increased level of activation and a strong emotional-motivational stress. Informational divergence is a threat to the 'self' and, therefore, the entire system of regulations (Jakubik, 1997; Millon \& Davis, 2005).

The underdevelopment of the cognitive system and of the structure of the 'self' is displayed in violence perpetrators by a lower or higher degree of inability to undergo internal structural transformation under the influence exerted by informational divergence. A frequent result is a constant desire to change the situation or environment, rather than to make appropriate changes to the information coded in the cognitive structures. A dominating position in the motivation of the behavior of violence perpetrators is, therefore, acquired by striving to maintain, protect, and elevate their own self-esteem, which is usually achieved by lowering the value of a partner (e.g. questioning her competence, professional status, and/or ascribing negative traits) by means of controlling her behavior, domination, and by the need of excessive social approval (e.g. they wish to be perceived as exceptionally decent, honest, and righteous individuals).

\section{CONCLUSION AND DIRECTIONS FOR FUTURE RESEARCH}

The results of the current study show that it is impossible to treat all family violence perpetrators as belonging to one and the same group because the personality profile of family violence perpetrators indicated the existence of four distinct subgroups, each with their own characteristics and implications for treatment. Nevertheless, the results reveal that the personality and behavior of these perpetrators remain closely connected with a deformed function of the structure of the 'self'. In the research devoted to differentiating types of male batterers (Gondolf 1993; Holtzworth-Munroe \& Stuart 1994; Saunders, 1992), frequently examined variables connected with family violence perpetration include cyclical or incidental character (i.e., those who go through the domestic violence cycle of tension, violence, and the honeymoon stage versus those who commit acts of violence sporadically), location of violence (i.e., at home and/ or elsewhere; aggressors whose violence is limited to their own family or those who also engage in violence against other people), and symptoms of psychopathology, most frequently in the form of psychiatric disorders (displaying symptoms versus not displaying such symptoms, but indicating other issues). It is therefore recommended that the character and location be taken into consideration in future research.

The criterion for identification of psychological disorders and social functioning without deeper analyses of the psychological properties and personality traits of aggressors is unfortunately too common. Only Dutton (2001) has pointed at emotional lability (i.e., emotional distance) when differentiating between violence perpetrators, suggesting that it presents a strong motivation to exercise control over a partner. Therefore, it seems that differentiating violence perpetrators on the basis of personality factors and temperament traits as mechanisms of regulation and integration of behavior may be important from both theoretical and practical standpoints. This could not only help us to understand family violence perpetration, but also influence unique and novel therapeutic actions tailored to certain types of perpetrators that address intrapsychic factors. In short, it is possible that this knowledge gained in this study may increase therapy effectiveness, first by making it possible to classify offenders into different groupings and second by providing the appropriately fitted responses. Current treatments may be ineffective due to the uniform way in which offenders are approached; it is possible that specific responses are needed for different types of perpetrators (Merk, deCastro \& Koops, 2005). While the most conducive context to the formation of individual personality traits is unknown, various factors exert an influence in triggering family violence perpetrators' acts of aggression. Therefore, it would be advisable to look for factors that target both the formation of personality structures and the mechanisms underlying activeness in further research.

\section{ENDNOTES}

1 Permission to conduct this research was obtained prior to the start of this study, and the study was carried out with full respect to ethical and legal procedures.

\section{RefERENCES}

Babcock, J.C., Canady, B., Graham, K.H. \& Schart, L. (2007). The evolution of battering interventions: From the dark ages into the scientific age. In: J. Hamal \& T. Nicholls (eds.). Family Therapy for domestic violence: A practitioner's guide to gen- 
der-inclusive research and treatment (pp. 215-244). New York, NY: Springer.

Barnett, O.W., Miller-Perrin, C.L. \& Perrin, R.D. (2004). Family violence across the lifespan ( $2^{\text {nd }}$ ed.). Thousand Oaks, CA: Sage.

Baumaister, R.F. \& Boden, J.M. (1998). Aggression and the self: High self-esteem, low self-control, and ego-threat. In: R.G. Geen \& E. Donnerstein (eds.). Human aggression: Theories, research and implications for social policy (pp. 111-137). San Diego, CA: Academic Press.

Bennett, L.W. \& Williams, O.J. (1999). Men who batter. In: R.L. Hampton (eds.). Family violence ( $2^{\text {nd }}$ ed., pp. 227-259). Thousand Oaks, CA: Sage.

Berger, E.M. (1962). The relation between expressed acceptance of self and expressed acceptance of others. Journal of Abnormal and Social Psychology, 47, 778-782.

Berkowitz, L. (1993). Aggression: Its causes, consequences, and control. Philadelphia, PA: Temple University Press.

Borgen, F.H. \& Barnett, D.C. (1987). Applying cluster analysis in counseling psychological research. Journal of Counseling Psychology, 34, 456-468.

Browne, K. D., \& Herbert, M. (1999). Zapobieganie przemocy w rodzinie [Prevention of Domestic Violence]. Warszawa: Wydawnictwo Szkolne i Pedagogiczne Spółka Akcyjna.

Brzeziński, J., Gaul, M., Hornowska, E. \& Jaworska, A. (2004). WAIS-R(PL) Skala Inteligencji Wechslera dla Dorostych - Wersja Zrewidowana. Renormalizacja [WAIS-R(PL) Wechsler Adult Intelligence - Revised Version. Renormalization]. Warszawa: Laboratory of Psychological Tests.

Buss, A.H. (1961). The psychology of aggression. New York, NY: Willey and Sons.

Buss, A.H. (1957). An Inventory assessing different kinds hostility. Journal of Consulting and Clinical Psychology, 21, 343-349.

Caesar, P.L. (1988). Exposure to violence in the families-of-origin among wife abusers and maritally nonviolent men. Violence and Victims, 3, 49-63.

Campbell, J.C., Sharps, P. \& Glass, N.E. (2000). Risk assessment for intimate partner violence. In: G.F. Pinard \& L. Pagani (eds.). Clinical assessment of dangerousness: Empirical contributions (pp. 136167). New York, NY: Cambridge University Press.

Caprara, G.V., Perugini, M. \& Barbaranelli, C. (1994). Studies of individual differences in aggression. In: M. Potegal \& J.F. Knutson (eds.). The dynamics of aggression: Biological and social processes in dyads and groups (pp. 123-153). Hillsdale, NJ: Lawrence Erlbaum Associates, Inc.

Drwal, R. (1979). Opracowanie Kwestionariusza Delta do pomiaru poczucia kontroli [Delta Development Questionnaire to measure sense of control]. Studia Psychologiczne, 18, 67-84.
Dutton, D.G. \& Golant, S.K. (1995). The Batterer: A psychological profile. New York, NY: Basic Books.

Dutton, D.G. (2001). Przemoc w rodzinie [Violence in the family]. Warszawa: Grupa Wydawnicza Bertelsmann Media.

Dutton, D.G. (2006). Rethinking domestic violence. Vancouver: UBC Press.

Ehrensaft, M.K., Cohen, P. \& Johnson, J.G. (2006). Development of personality disorder symptoms and the risk for partner violence. Journal of $A b$ normal Psychology, 115, 474-483.

Eliasz, A. (1981). Temperament a system regulacji stymulacji [Temperament and control system stimulation]. Warszawa: Państwowe Wydawnictwo Naukowe.

Frączek, A. (2002). Agresja interpersonalna: opis i analiza z perspektywy psychologii społecznej [Interpersonal aggression: description and analysis from the perspective of social psychology]. In: Ł. Jurasz-Dudzik (ed.). Agresja i człowiek. Glosy o nienawiści i przemocy. Ujęcie interdyscyplinarne [Aggression and man. The voices of hatred and violence]. Warszawa: Wydawnictwo Sic!

Gasiul, H. (1993). Oblicza „Ja” w świetle wybranych koncepcji psychologicznych. Pojęcie rozwoju, patologia [Faces of the "I" in the light of some psychological concepts. The notion of the development of pathology]. Bydgoszcz: WSP.

Gierowski, J.K. (2000). Psychologiczne wyznaczniki przestępczości [Psychological determinants of crime]. In: J. Strelau (ed.). Psychologia [Psychology] (pp. 710-729). Gdańsk: GWP.

Goldstein, D. \& Rosenbaum, A. (1985). An evaluation of the self-esteem of martially violent men: family relations. Journal of Applied and Family and Child Studies, 34, 525-428.

Gondolf, E.W. (1993). Male batterers. In: R. Hampton (eds.). Family violence: Prevention and treatment (pp. 230-257). Newbury Park, CA: Sage.

Hamberger, L.K. \& Hastings, J.E. (1986). Personality correlates of men who abuse their partners: A cross-validation study. Journal of Family Violence, 1, 112-134.

Hare, R. D. (1970). Psychopathy: theory and research. New York: Willey.

Hare, R.D. (2012). Psychopaci sq wśród nas [Psychopaths among us]. Krakow: Znak.

Hare, R.D. \& Jutai, J. (1986). Psychopathy, stimulation seeking and stress. In: J. Strelau, F. Parley \& A. Gale (eds.). The biological bases of personality and behavior. Washington, D.C.: Hemisphere.

Herzberger, S.D. (2002). Przemoc domowa. Perspektywa psychologii społecznej [Domestic violence: The perspective of social psychology]. Warszawa: Państwowa Agencja Rozwiązywania Problemów Alkoholowych.

Holtzworth-Munroe, A. \& Stuart, G.L. (1994). Typologies of male batterers: Three subtypes and the 
differences among them. Psychological Bulletin, 116, 476-497.

Holtzworth-Munroe, A., Meehan, J.C., Herron, K., Rehman, U. \& Stuart, G.L. (2000). Testing the Holtzworth-Munroe and Stuart (1994) batterer typology. Journal of Consulting and Clinical Psychology, 68, 1000-1019.

Jacob, T. (1987). Family interaction and psychopathology: Theories, method and findings. New York, NY: Plenum.

Jacobson, N. (1993). Domestic violence: What are the marriages like? Anaheim, CA: American Association for Marriage and Family Therapy.

Johnson, M.P. (2006). Conflict and control: Gender symmetry and asymmetry in domestic violence. Violence Against Women, 12, 1003-1018.

Jakubik, A. (1997). Zaburzenia osobowości [Personality disorders]. Warszawa: Wydawnictwo Lekarskie PZWL.

Januszewski, A. (1992). Funkcje samoakceptacji w poznawaniu siebie i innych [Functions of self-acceptance in understanding yourself and others]. In: A. Biela \& Cz. Walesa (eds.). Problemy wspótczesnej psychologii [Problems of modern psychology] (pp. 69-75). Lublin: PTP.

Kaufman, J. \& Zigler, E. (1999). The intergenerational transmission of child abuse. In: D. Cicchetti \& V. Carlson (eds.). Child maltreatment: Theory and research on the causes and consequences of child abuse and neglect (pp. 129-150). Cambridge: Cambridge University Press.

Krahé, B. (2005). Agresja [Aggression]. Gdańsk: GWP.

Kilpatrick, D.G. (2004). What is violence against women: Defining and measuring the problem. Journal of Interpersonal Violence, 19, 1209-1234.

Kubacka-Jasiecka, D. (2006). Agresja i autodestrukcja z perspektywy obronno-adaptacyjnych dażeń $J A$ [Aggression and self-destruction from the perspective of defense and adaptation efforts]. Kraków: Wydawnictwo Uniwersytetu Jagiellońskiego.

Łukaszewski, W. (1983). Osobowość, orientacja temporalna, ustosunkowanie do zmian [Personality, temporal orientation, response to change]. Wrocław: Uniwersytet Wrocławski.

Merk, W., deCastro, B.O. \& Koops, W. (2005). The distinction between reactive and proactive aggression: Utility for theory, diagnosis, and treatment. European Journal of Developmental Psychology, 2, 197-220.

Millon, T. (1996). Disorders of personality: DSM-IV and beyond. New York, NY: Wiley.

Millon, T. (1999). Models of personality and its disorders. In: T. Millon, P. Blaney \& R.D. Davis (eds.). Oxford Textbook of Psychopathology (pp. 485-522). Oxford: Oxford Press.

Millon, T. \& Davis, R. (2005). Zaburzenia osobowości we wspótczesnym świecie [Personality disorders in the world today]. Warszawa: Instytut Psychologii Zdrowia, Polskie Towarzystwo Psychologiczne.

Nęcka, E. (2000). Inteligencja [Intelligence]. In: J. Strelau (ed.). Psychologia. Podręcznik Akademicki [Psychology, Academic Handbook]. Gdańsk: Gdańskie Wydawnictwo Psychologiczne.

Oleś, P.K. (2013). Wprowadzenie do psychologii osobowości [Introduction to the psychology of personality]. Wydawnictwo Naukowe: Scholar.

O’Leary, K.D. (1993). Through a psychological lens: Personality traits, personality disorders, and levels of violence. In: R.J. Gelles \& D.R. Loseke (eds.). Current controversies on family violence (pp. 7-30). Newbury Park, CA: Sage.

Papadakaki, M., Tzamalouka, G.S., Chatzifotios, S. \& Chliaoutakis, J. (2009). Seeking for risk factors of intimate partner violence (IPV) on a Greek national sample: the role of self-esteem. Journal of Interpersonal Violence, 24, 732-750.

Pastwa-Wojciechowska, B. (2004). Naruszanie norm prawnych w psychopatii. Analiza kryminologiczno-psychologiczna [Violations of legal norms in psychopathy. A criminological-psychological analysis]. Gdańsk: Wydawnictwo Uniwersytetu Gdańskiego.

Reykowski, J. (1978). Podstawowe mechanizmy regulacji społecznego zachowania się [Basic mechanisms of regulation of social behavior]. In: J. Reykowski (ed.). Teorie osobowości a zachowanie prospoteczne [Theories of personality and social behavior]. Warszawa: PWN.

Reykowski, J. (1986). Motywacja postawy prospoteczne a osobowość [Motivation, prosocial attitudes, and personality]. Warszawa: PWN.

Reykowski, J. (1992). Emocje, motywacja, osobowość [Emotion, motivation, personality]. Warszawa: PWN.

Rode, D. (2010a). Typology of perpetrators of domestic violence. Polish Psychological Bulletin, 41, 12-23.

Rode, D. (2010b). Interakcyjny model uwarunkowań aktów przemocy w rodzinie [Interaction model of the conditions for violent acts in the family]. Problems of Forensic Science, LXXXIV, 336-355.

Rode, D. (2011). Psychologiczne uwarunkowania przemocy w rodzinie. Charakterystyka sprawców [Psychological aspects of domestic violence: characteristics of perpetrators]. Katowice: Wydawnictwo Uniwersytetu Śląskiego.

Ross, J.M. (2011). Personality and situational correlates of self-reported reasons for intimate partner violence among women versus men referred to batterers' intervention. Behavioral Sciences and the Law, 29, 711-727.

Ross, J.M. \& Babcock, J.C. (2009). Proactive and reactive violence among intimate partner violent men diagnosed with antisocial and borderline personality disorder. Journal of Family Violence, 24, 607-617. 
Rotter, J.B. (1975). Some problems and misconceptions related to the construct of internal versus external control. Journal of Consulting in Clinical Psychology, 43, 56-67.

Saunders, D.G. (1992). A typology of men who batter. American Journal of Orthopsychiatry, 62, 264-275.

Saunders, D.G. (1995). Prediction of wife assault. In: J.C. Campbell (eds.). Assessing dangerousness: Violence by sexual offenders, batterers and child abusers (pp. 68-95). Newburg Park, CA: Sage.

Stanik, J.M., Roszkowska, A. \& Kucharewicz, J. (2006). Psychologiczna diagnoza zachowań agresywnych w świetle badań Skalą Agresji Buss-Durkee (SABD) - wyniki badań i normalizacja testu [Psychological diagnosis of aggressive behavior in the light of Aggression Scale Buss-Durkee (SABD) - the results of the test and normalization]. In: J. Stanik (ed.). Zastosowanie wybranych technik diagnostycznych w psychologicznej praktyce klinicznej i sqdowej [The use of selected diagnostic techniques in psychological clinical and judicial practice]. Katowice: Wydawnictwo Uniwersytetu Śląskiego.

Strelau, J. (2001). The concept and status of trait in research on temperament. European Journal of Personality, 15, 311-324.

Strelau, J. (2006). Temperament jako regulator zachowania z perspektywy pótwiecza badań [Temperament as a regulator of behavior from the perspective of half a century of research]. Gdańsk: Gdańskie Wydawnictwo Psychologiczne.

Strelau, J. \& Zawadzki, B. (1998). Kwestionariusz temperamentu PTS. Podręcznik [PTS Temperament Questionnaire]. Warszawa: Pracownia Testów Psychologicznych PTP.

Toch, H. (1993). Good violence and bad violence: Self-presentations of aggressors through accounts and war stories. In: R.B. Felson \& J.T. Tedeschi (eds.). Aggression and violence: Social interactionist perspectives. Washington, D.C.: American Psychological Association.

Walsh, Z., Swogger, M.T., O'Connor, B.P., Schonbrun, Y.C., Shea, T.M. \& Stuart, G.L. (2010). Subtypes of violence perpetrators among male and female psychiatric patients. Journal of Abnormal Psychology, 119, 563-574.

Weitzman, J. \& Dreen, K. (1992). Wife beating: a view of the marital dyad. Social Casework, 63, 259-265.

Wiehe, V.R. (1998). Understanding family violence: treating and preventing partner, child, sibling, and elder abuse. Thousand Oaks, CA: Sage. 